УДК 657.1

DOI: https://doi.org/10.26642/jen-2019-3(89)-129-136

О.Д. Панченко, аспірант

ННЦ «Інститут аграрної економіки»

\title{
Механізм функціонування управлінського обліку в сільськогосподарських підприємствах
}

\author{
(Представлено: д.е.н., дои.. Шерстюк О.Л.)
}

\begin{abstract}
Трансформація української економіки вагомо впливає на існування підприємств, щзо спонукає їх пристосовуватися до постійних змін на всіх рівнях господарсько-управлінської діяльності. Функиіонування сільськогосподарських підприємств вимагає від оточуючого середовища особливої уваги. Управлінський облік у сільськогосподарській сфері має охоплювати планування, реалізачія управлінських рішень, облік, аналіз, контроль та коригування як єдиний безперервний циклічний прочес. Нині на більшості вітчизняних підприємств взагалі відсутній управлінський облік як такий. Його прояв пов'язаний лише із прийняттям управлінських рішень керівними ланками суб'єктів господарювання $і$ не спрямований на комплексний аналіз діяльності підприсмства, планування його показників, дослідження причин відхилення від намічених иілей тощзо.

Метою дослідження є визначення особливостей функиіонування управлінського обліку як иілісного механізму в сільськогосподарських підприємствах.

При проведенні дослідження було використано такі методи: аналіз і синтез; класифікаџійноаналітичний. Теоретико-методологічною основою дослідження є праці науковців, щзо займалися вивченням управлінського обліку, специффікою його існування на підприємстві.

Узагальнено класифікаџію етапів функиіонування (упровадження, організації) управлінського обліку. Визначено, щзо більшість науковиів питання функціонування управлінського обліку в повному масштабі не описують, а зосереджують увагу лише на його впровадженні на підприємстві, тобто на налагодженні базових елементів і не розглядають питання подальшого його вдосконалення. Розроблено механізм функиіонування управлінського обліку в сільськогосподарських підприємствах. Запропоновано алгоритм прочесу впровадження системи управлінського обліку. Наведено показники ефективності існування системи управлінського обліку.

Отже, механізм функиіонування управлінського обліку в сільськогосподарських підприємствах $\epsilon$ комплексною системою, яка складається із процесів упровадження, оцінки, аналізу, контролю та вдосконалення, щз мають враховувати специфіку діяльності суб'єкта господарювання.
\end{abstract}

Ключові слова: управлінський облік; сільське господарство; механізм функиіонування; алгоритм процесу упровадження; ефективність існування.

Постановка проблеми. Трансформація української економіки вагомо впливає на існування підприємств, що спонукає їх пристосовуватися до постійних змін на всіх рівнях господарськоуправлінської діяльності. Функціонування сільськогосподарських підприємств вимагає від оточуючого середовища особливої уваги. Передусім це пов'язано зі специфікою виробничого процесу та його обліково-аналітичним відображенням, яке можна розглядати через управлінський облік як цілісну систему.

Управлінський облік у сільськогосподарській сфері має охоплювати планування, реалізація управлінських рішень, облік, аналіз, контроль та коригування як єдиний безперервний циклічний процес. Нині на більшості вітчизняних підприємств взагалі відсутній управлінський облік як такий. Його прояв пов'язаний лише із прийняттям управлінських рішень керівними ланками суб'єктів господарювання і не спрямований на комплексний аналіз діяльності підприємства, планування його показників, дослідження причин відхилення від намічених цілей тощо.

Аналіз останніх досліджень та публікацій. Теоретико-методологічні та практичні аспекти існування управлінського обліку відображені в працях багатьох науковців, таких як: Ф.Ф. Бутинець [2], О.В. Лишиленко [6], Б.В. Мельничук [8], В.А. Москаленко [9], О.О. Олійник [10] та багато інших. Але питання дослідження функціонування управлінського обліку на сільськогосподарських підприємствах як комплексного механізму залишається доволі актуальним.

Постановка завдання. Метою статті є визначення особливостей функціонування управлінського обліку як цілісного механізму в сільськогосподарських підприємствах.

Викладення основного матеріалу. Удосконалення управління діяльністю господарюючих суб'єктів аграрної сфери взагалі і вдосконалення методів та прийомів управлінського обліку зокрема визначається складними завданнями реформування галузі та високим рівнем конкуренції. У цих умовах система управління має забезпечувати ефективність виконання бізнес-процесів, пов'язаних із рухом товару до

(C) О.Д. Панченко, 2019 
кінцевого споживача, а менеджмент - отримати повну та достовірну інформацію для прийняття управлінських рішень, проведення аналізу та забезпечення контролю функціонування поточних процесів на різних рівнях [5, с. 201].

В управлінському обліку реалізується інтеграція різних функцій управління: планування, обліку, аналізу, контролю. Дійсно, управлінський облік - це не виключно бухгалтерський облік чи його якась певна частина. Це набагато ширша, дієвіша інформаційна система. Те, що управлінський облік містить в собі багато елементів з різних галузей знань, різних наук, як-от планування, бухгалтерський облік, аналіз господарської діяльності, контроль, - не недолік. Це, навпаки, позитивна його сторона. Управлінський облік є своєрідним містком, який з'єднує бухгалтерський облік з процесом управління [8]

В цілому упровадження управлінського обліку доволі складний процес, який кожен науковець трактує по-різному.

Бутинець Ф.Ф., Чижевська Л.В., Герасимчук Н.В. вважають, що організація бухгалтерського управлінського обліку на підприємстві включає три етапи.

На першому, методологічному етапі, обирається модель управлінського обліку залежно від його мети, визначаються об'єкти та методи обліку витрат, елементи методу бухгалтерського обліку, які будуть слугувати для формування інформації, необхідної для прийняття управлінських рішень (план рахунків управлінського обліку, склад калькуляційних статей, тощо).

На другому, технічному етапі, обирається склад регістрів аналітичного обліку, форми внутрішньої звітності, визначаються напрямки руху інформації всередині підприємства.

Третій, організаційний етап, передбачає розподіл обов'язків між працівниками в системі управлінського обліку [2].

Лишиленко О.В. виокремлює три етапи, які проходить кожне підприємство при побудові системи управлінського обліку: методологічний, методичний, технічний.

На першому етапі обирається модель управлінського обліку залежно від завдань, вирішення яких покликана забезпечити створена облікова система, визначаються об'єкти витрат та ознаки узагальнення в обліку інформації для аналізу за основними сегментами ринку.

Другий етап характеризується підбором елементів методу управлінського обліку, які забезпечують формування інформації, необхідної для прийняття незалежних управлінських рішень; визначення плану рахунків бухгалтерського обліку; підбір складу регістрів синтетичного і аналітичного обліку; вибір складу калькуляційних статей для обліку витрат; розробка форм внутрішньої звітності і контролю за здійсненням операцій та виконанням виробничих завдань.

Третій етап передбачає визначення осіб і розмежування обов'язків між вказаними працівниками, які будуть задіяні в системі збору й опрацювання інформації управлінського обліку [6, с. 22-23].

Турова Л.Л. та Костюнік О.В. пропонують три етапи впровадження системи управлінського обліку.

Перший етап містить: постановку мети; планування і прогнозування; формування інформаційної бази; диференціацію витрат; аналіз і контроль; коригування планів.

Другий етап враховує організацію системи управлінського обліку: опрацювання набору підконтрольних показників; розрахунок і аналіз основних показників у оперативному режимі; організацію інформаційного забезпечення; виявлення неприпустимих відхилень та «вузьких місць».

Третій етап передбачає налагодження регулярних процедур в оперативному режимі: документування; моніторинг; інформаційне та економічне моделювання; економічний аналіз [12, с. 39].

Визначальним і найбільш трудомістким етапом створення і розвитку управлінського обліку на підприємстві, на думку І.Б. Плотніченко, .є розробка (постановка) системи управлінського обліку, що передбачає здійснення п'яти стадій:

1. Дослідно-аналітична (діагностична) стадія - необхідно визначитися з ключовими вимогами до системи управління, провести діагностику організаційної структури, специфіки функціонування підприємства та практики прийняття рішень, здійснити аналіз бізнес-процесів з метою їх оптимізації, дослідити діючу систему бухгалтерського обліку та інші ключові моменти для визначення цілей $\mathrm{i}$ пріоритетів розвитку підприємства.

2. Методологічна стадія - передбачає вибір моделі управлінського обліку, уточнення принципів його організації, визначення об'єктів і системи обліку витрат, методів калькулювання собівартості продукції. Досить вагомим моментом є створення й функціонування системи обліку за центрами відповідальності.

3. Документальна стадія - передбачає розробку форм внутрішньої звітності, визначення i затвердження системи документообігу, організацію інформаційних потоків на підприємстві.

4. Стадія автоматизації інформаційного процесу на підприємстві - це визначальний чинник дієвості системи управлінського обліку, адже для досягнення ефективності прийнятих управлінських рішень обробка й надання даних має здійснюватися інтегровано й оперативно.

5. Організаційна стадія - завершальна стадія розробки системи управлінського обліку, що передбачає затвердження обраної методики в наказі про організацію управлінського обліку, а також створення служби 
управлінського обліку як додаткової ланки управління, розподіл відповідних обов'язків між працівниками, формування посадових інструкцій [11].

Бива В.В. та Матюшіна Ю.І. пропонують формування системи управлінського обліку на підприємствах виконувати в декілька етапів.

Перший етап є характерним для підприємств, що існують досить довго. Завданнями етапу є опис і аналіз існуючої інформаційної системи підприємства (переважно системи бухгалтерського обліку). Результатом цього етапу є схеми організаційної структури управління, інформаційних потоків підприємства, опис системи бухгалтерського обліку. На цьому етапі також необхідно визначити особливості та недоліки діючої системи управлінського обліку.

На другому етапі визначається якісний та кількісний склад інформації, необхідної для ефективного управління підприємством: виявляються «пробіли» існуючої інформаційної системи, з'ясовуються причини цього, оцінюється об'єм змін у системі управління.

На третьому етапі має бути представлена відповідна формалізована система, яка здатна збирати, обробляти і надавати інформацію, що відповідає потребам керівництва. На цьому етапі виокремлюються центри відповідальності - сегменти всередині підприємства, що очолюють відповідальні особи, які приймають рішення.

Четвертий етап характеризується побудовою системи управлінської звітності, яка являє собою сукупність звітів, що складаються центрами відповідальності та включає всю необхідну для обліково-аналітичних спеціалістів інформацію з заданим рівнем деталізації.

На п’ятому етапі відбувається конструювання системи управлінського обліку. Головною метою аналізу являється оцінка фінансово-господарської діяльності підприємства на основі управлінської аналітичної звітності та розробка рекомендацій по ії удосконаленню, а також своєчасне виявлення та усунення недоліків у діяльності господарюючого суб'єкта, знаходження резервів покращення фінансового стану.

Заключним шостим етапом формування системи управлінського обліку на підприємствах є постановка системи фінансового планування, яка складається із систем бюджетного планування діяльності структурних підрозділів підприємства і системи вільного бюджетного планування діяльності підприємства [1, с. 61-62].

Основними етапами, притаманними управлінському обліку в сільському господарстві, на думку Т.А. Крушельницької та Г.С. Павлової, є такі:

1. Визначення кінцевої мети діяльності; формування інформаційної бази щодо витрат та доходів (формування оперативних, виробничих, зведених звітів);

2. Розробка річного та перспективного планів; розробка планів для виробничих підрозділів (тракторна бригада, молочно-товарна ферма, автопарк тощо) у розрізі півперіодів або технологічних процесів (оранка, весняно-польові роботи, збирання урожаю);

3. Диференціація витрат (за періодами виникнення, за центрами відповідальності, за калькуляційними статтями та за іншими ознаками); контроль та аналіз процесу виробництва та факторів, що на нього впливають;

4. Коригування поточних та стратегічних планів.

На кожному з етапів в тому чи іншому порядку можуть виконуватися такі дії: визначення прийнятної для підприємства системи економічних показників; визначення інформаційних джерел та організація оперативного надходження та обробки даних; оперативне визначення основних економічних показників; виявлення і оцінка відхилень від планових та нормативних показників; виявлення «вузьких місць» та розробка алгоритму щодо їх усунення.

При виконанні дій застосовуються певні процедури, серед яких основними є: розробка та впровадження нових форм та методів накопичення інформації; розробка оперативних, поточних та стратегічних планів, економічних прогнозів; моніторинг виробничо-господарської діяльності; калькулювання собівартості на різних етапах виробничого процесу; розрахунок основних економічних показників та факторів, що на них впливають [4].

Довжик О.О. та Гаркуша С.А. систему організації управлінського обліку поділяють на чотири етапи: підготовчий, методичний, технічний та організаційний.

На підготовчому етапі аналізують існуючу організаційну форму господарювання; визначають технологію вирощування біологічних активів і виробництва сільськогосподарської продукції (робіт, послуг); виокремлюють центри відповідальності (сегменти).

На методичному - визначають цілі та напрями класифікації витрат, собівартості й доходів; вибирають оптимальну систему обліку та калькулювання собівартості продукції; метод розрахунку собівартості продукції; порядок розподілу непрямих витрат; визначають доходи та фінансові результати в управлінському обліку, порядок ведення управлінського обліку активів і пасивів.

Технічний етап враховує в себе визначення та розробку форм первинних і зведених документів за об'єктами управлінського обліку, графіка документообігу, плану рахунків, форм бюджетів i внутрішньогосподарської звітності; встановлення періодичності та послідовності заповнення регістрів обліку й управлінської звітності, здійснення аналізу, контролю та бюджетування; вибір програмного забезпечення. 
Організаційний етап складається з проектування організаційної структури відділу управлінського обліку 3 його функціями, завданнями і виконавцями; розподіл обов'язків між працівниками центрів відповідальності й відділом управлінського обліку та встановлення взаємозв'язків між ними й іншими службами підприємства; розробка внутрішніх положень щодо організації управлінського обліку. Усі ці етапи є нерозривними складовими єдиної правильно організованої системи управління в підприємстві $[13,3]$.

3 наведеного вище можна зробити висновок, що серед науковців не існує єдиної класифікації етапів функціонування управлінського обліку (табл. 1). Це може бути пов'язано із відсутністю чіткої позиції щодо місця управлінського обліку в системі бухгалтерського та управління в цілому.

Таблиия 1

Класифікаџія етапів функиіонування (упровадження, організації) управлінського обліку

\begin{tabular}{|c|c|}
\hline Автор & Етапи \\
\hline \multirow{3}{*}{$\begin{array}{l}\text { Бутинець Ф.Ф., } \\
\text { Чижевська Л.В., } \\
\text { Герасимчук Н.В. }\end{array}$} & 1. Методологічний \\
\hline & 2. Технічний \\
\hline & 3. Організаційний \\
\hline \multirow{3}{*}{ Лишиленко О.В. } & 1. Методологічний \\
\hline & 2. Методичний \\
\hline & 3. Технічний \\
\hline \multirow{3}{*}{$\begin{array}{l}\text { Турова Л.Л., } \\
\text { Костюнік О.В. }\end{array}$} & $\begin{array}{l}\text { 1. Постановка мети; планування і прогнозування; формування інформаційної бази; } \\
\text { диференціація витрат; аналіз і контроль; коригування планів }\end{array}$ \\
\hline & 2. Організація системи управлінського обліку \\
\hline & 3. Налагодження регулярних процедур в оперативному режимі \\
\hline \multirow{4}{*}{ Плотніченко І.Б } & 1. Розробка (постановка) системи управлінського обліку \\
\hline & 2. Функціонування (використання і обслуговування) системи управлінського обліку \\
\hline & 3. Оцінювання впровадженої системи управлінського обліку \\
\hline & 4. Удосконалення діючої системи управлінського обліку \\
\hline \multirow{6}{*}{$\begin{array}{c}\text { Бива В.В., } \\
\text { Матюшіна Ю.І. }\end{array}$} & 1. Опис і аналіз існуючої інформаційної системи підприємства \\
\hline & $\begin{array}{l}\text { 2. Визначення якісного та кількісного складу інформації, необхідної для ефективного } \\
\text { управління підприємством }\end{array}$ \\
\hline & $\begin{array}{l}\text { 3. Представлення формалізованої системи, яка здатна збирати, обробляти і надавати } \\
\text { інформацію, що відповідає потребам керівництва }\end{array}$ \\
\hline & 4. Побудова системи управлінської звітності \\
\hline & 5. Конструювання системи управлінського обліку \\
\hline & 6. Постановка системи фінансового планування \\
\hline \multirow{4}{*}{ Олійник О.О. } & $\begin{array}{l}\text { 1. Виявлення стану діючого обліку: вивчення бізнесу, логістика процесів, зовнішне } \\
\text { середовище, система документообігу та звітності }\end{array}$ \\
\hline & $\begin{array}{l}\text { 2. Визначення потреб в управлінській інформації: окреслення управлінських завдань та } \\
\text { потреб, класифікація витрат за центрами відповідальності }\end{array}$ \\
\hline & 3. Створення системи обліку: робота інформаційно-аналітичного центру \\
\hline & 4. Оцінка ефективності обліку: дієвість прийняття управлінських рішень \\
\hline \multirow{4}{*}{$\begin{array}{l}\text { Довжик О.О., } \\
\text { Гаркуша С.А. }\end{array}$} & 1. Підготовчий \\
\hline & 2. Методичний \\
\hline & 3. Технічний \\
\hline & 4. Організаційний \\
\hline \multirow{6}{*}{ Москаленко В.А. } & 1. Видання і затвердження управлінської облікової політики організації \\
\hline & $\begin{array}{l}\text { 2. Створення і затвердження пакета внутрішніх організаційних стандартів управлінського } \\
\text { обліку }\end{array}$ \\
\hline & 3. Затвердження системи рахунків управлінського обліку \\
\hline & 4. Затвердження форм первинних документів та звітності управлінського обліку \\
\hline & 5. Створення системи бюджетів сільськогосподарських підприємств \\
\hline & 6. Вибір методики контролю над виконанням бюджетів \\
\hline \multirow{3}{*}{ Лукін В.О. } & 1. Вивчення потреб підприємства в інформації управлінського обліку \\
\hline & 2. Розробка загального плану виконання робіт та його конкретизація за окремими етапами \\
\hline & $\begin{array}{l}\text { 3. Проведення робіт з впровадження системи управлінського обліку та коректування (у } \\
\text { випадку необхідності) плану робіт }\end{array}$ \\
\hline \multirow{4}{*}{$\begin{array}{c}\text { Крушельницька Т.А., } \\
\text { Павлова Г.С }\end{array}$} & 1. Визначення кінцевої мети \\
\hline & 2. Розробка планів. \\
\hline & 3. Диференціація витрат \\
\hline & 4. Коригування поточних та стратегічних планів \\
\hline
\end{tabular}


Більшість науковців питання функціонування управлінського обліку в повному масштабі взагалі не описують, а зосереджують увагу лише на його впровадженні на підприємстві, тобто на налагодженні базових елементів і не розглядають питання подальшого його вдосконалення.

Управлінський облік у сільськогосподарських підприємствах необхідно досліджувати, виходячи зі специфічних особливостей цієї сфери, таких як: нестандартна тривалість виробничого циклу, використання біологічних активів; віддаленість виробничих центрів від управлінської ланки; специфічний ринок збуту; неоднорідний вихід готової продукції; залежність від погодних умов тощо.

Автор вважає, що функціонування управлінського обліку не можна розглядати лише як процес його впровадження на підприємстві. Це має бути безперервний механізм, який охоплюватиме цикл процесів, що містять заходи, пов'язані з його упровадженням, аналізом, контролем і вдосконаленням протягом усього періоду існування підприємства (рис. 1). Процес упровадження системи управлінського обліку доцільно розділити на 5 етапів: підготовчий (інформаційно-дослідний); методологічний (структурнологічний); технічний (програмно-формалізований); організаційний (функціонально-розпорядчий); управлінський (табл. 2).

Таблиия 2

Алгоритм процесу впровадження системи управлінського обліку на сільськогосподарських підприємствах

\begin{tabular}{|c|c|}
\hline Назва етапу & План дій \\
\hline Підготовчий & $\begin{array}{l}\text { 1. Аналіз економічної, політичної та соціальної ситуації в країні: } \\
\text { - дослідити ринковий попит на товар; } \\
\text { - оцінити позиції конкурентів у ринковому просторі, купівельну спроможність населення; } \\
\text { - проаналізувати рівень інфляції, валютний курс, позицію країни на світовій арені; } \\
\text { - дослідити податкову систему та податкову політику; } \\
\text { - вивчити особливості нормативно-законодавчої бази з питань обліку в сільському } \\
\text { господарстві, } \\
\text { - проаналізувати рівень соціального розвитку. } \\
\text { 2. Провести аналіз бізнес-процесів. Установити взаємозв’язки з контрагентами: } \\
\text { - визначити потенційних постачальників; } \\
\text { - знайти внутрішні та зовнішні ринки збуту; } \\
\text { - укласти договори }\end{array}$ \\
\hline $\begin{array}{c}\text { Методологічний } \\
\text { (структурно- } \\
\text { логічний) }\end{array}$ & $\begin{array}{l}\text { 1. Визначити мету, завдання, об’єкти, суб’єктів та методи обліку. } \\
\text { 2. Здійснити поділ витрат за різними класифікаційними ознаками залежно від особливостей } \\
\text { виробничо-фінансової діяльності. } \\
\text { 3. Згрупувати показники, що підлягатимуть аналізу, та визначити специфіку їх розрахунку. } \\
\text { 4. Визначити порядок формування доходів і фінансових результатів }\end{array}$ \\
\hline $\begin{array}{c}\text { Технічний } \\
\text { (програмно- } \\
\text { формалізований) }\end{array}$ & $\begin{array}{l}\text { 1. Розробити і затвердити форми первинних документів та зведених регістрів синтетичного } \\
\text { i аналітичного обліку залежно від видів продукції, центрів розподілу витрат тощо. } \\
\text { Установити вимоги та періодичність щодо їх опрацювання (документообігу, аналізу, } \\
\text { аудиту) та формування внутрішньої звітності. } \\
\text { 2. Налагодити систему автоматизації } \\
\text { 3. Налаштувати програмні продукти інформаційної системи відповідно до вимог } \\
\text { управлінського обліку }\end{array}$ \\
\hline $\begin{array}{c}\text { Організаційний } \\
\text { (функціонально- } \\
\text { розпорядчий) }\end{array}$ & $\begin{array}{l}\text { 1. Налагодити схему побудови облікової системи на підприємстві. } \\
\text { 2. Розподілити обов'язки, пов'язані із веденням управлінського обліку, між працівниками, } \\
\text { призначити відповідальних. } \\
\text { 3. Установити систему взаємозв'язків між відділами (підрозділами). } \\
\text { 4. Затвердити (узгодити, доповнити) внутрішні документи, необхідні для регламентації } \\
\text { ведення управлінського обліку, такі як: Наказ про облікову політику, Наказ про організацію } \\
\text { ведення управлінського обліку, положення, пов’язані з веденням управлінського обліку, } \\
\text { посадові інструкції тощо }\end{array}$ \\
\hline Управлінський & $\begin{array}{l}\text { Доцільно поділити на два: } \\
\text { - етап підготовки управлінського рішення, що містить в собі формування завдання, яке } \\
\text { необхідно вирішити, аналіз отриманої та згенерованої інформації, що впливатиме на } \\
\text { результат та сам процес прийняття рішення, враховуючи призначення відповідальних за } \\
\text { досягнення зазначених результатів; } \\
\text { - узгодити прийняті рішення із уже затвердженими, нормативними чи плановими й даними } \\
\text { фінансового обліку як такого, що регулюєтья чіткою законодавчою базою та податковим } \\
\text { обліком }\end{array}$ \\
\hline
\end{tabular}

Особливої уваги аналіз системи управлінського обліку вимагає в період відхилення фактичних показників (процесів) від планових, зміни стратегії підприємства, зниження конкурентоспроможної позиції підприємства на ринку, змін у зовнішньому середовищі. Своєчасне отримання інформації про вказані зміни дає можливість оперативно реагувати і приймати конструктивні рішення для уникнення можливих втрат. 


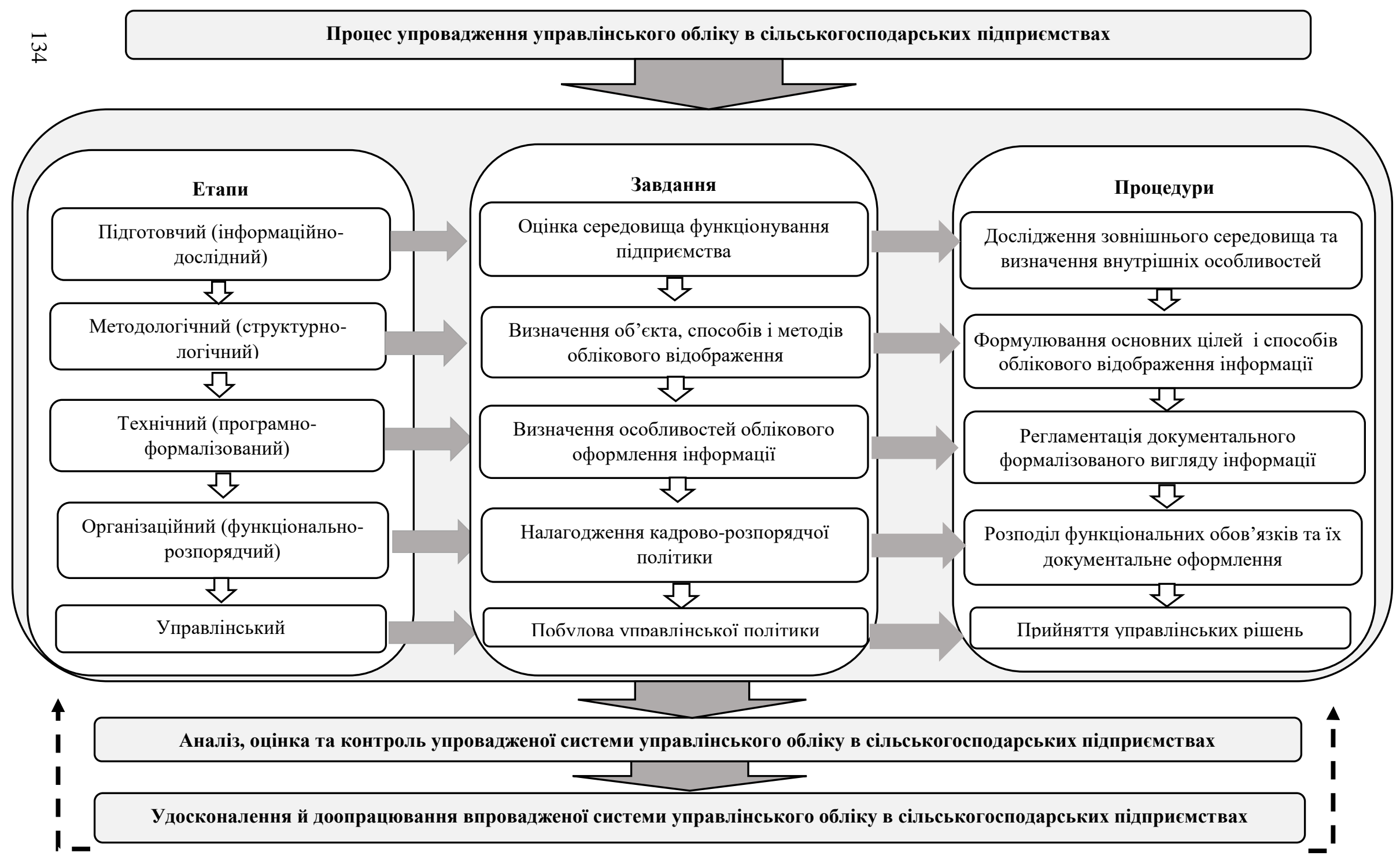

Довідка: розробка автора

Рис. 1. Механізм функиіонування управлінського обліку в сільськогосподарських підприємствах 
Тому необхідно щоденно контролювати фактичні показники витрат із обсягом виконаних робіт, якщо триває процес виробництва, або одержаною продукцією шляхом порівняння їх із плановими чи нормативними даними.

У разі виявлення неефективного функціонування системи управлінського обліку необхідно одразу здійснювати ії̈ коригування шляхом перегляду та вдосконалення основних етапів процесу упровадження. Для того, щоб не починати з нуля весь процес, необхідно проаналізувати ключові його компоненти і з’ясувати, який саме дав збій, або знайти помилку, що привела до цього, і терміново їі усунути.

Аналізуючи систему управлінського обліку, доцільно розглянути ефективність ії існування, яка пов'язана із можливістю комплексної оцінки функціонування сільськогосподарського підприємства, аналізом та контролем його основних процесів, побудовою майбутньої стратегії (рис. 2).

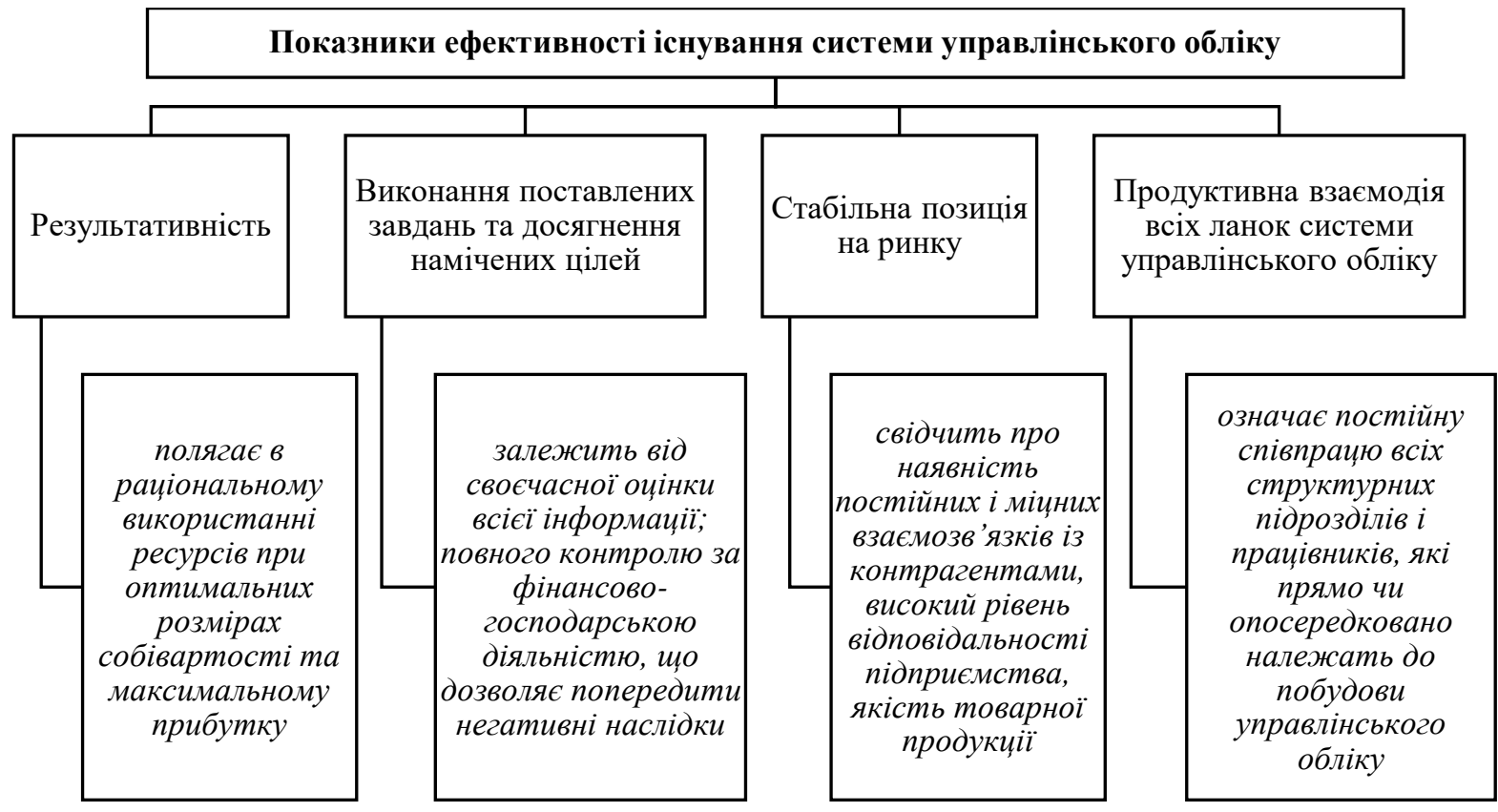

Довідка: розробка автора

\section{Рис. 2. Показники ефективності існування системи управлінського обліку}

Висновки 3 проведеного дослідження. Механізм функціонування управлінського обліку в сільськогосподарських підприємствах $є$ комплексною системою, яка складається із процесів упровадження, оцінки, аналізу, контролю та вдосконалення, що мають враховувати специфіку діяльності суб'єкта господарювання. Важливим моментом є дослідження ефективності функціонування системи управлінського обліку, яка дозволяє реально оцінити дієвість запровадженого механізму.

Перспективним напрямом подальшого дослідження $\epsilon$ практичне впровадження механізму функціонування управлінського обліку в сільськогосподарських підприємствах.

\section{Список використаної літератури:}

1. Бива В.В. Система управлінського обліку: сутність завдання та етапи впровадження / В.В. Бива, Ю.І. Матюшіна // Економіка та держава. - 2015. - № 1. - С. 60-62.

2. Бутинець Ф.Ф. Бухгалтерський управлінський облік : навч. посібник / Ф.Ф. Бутинеиь, Л.В. Чижевська, Н.В. Герасимчук. - Житомир : ЖІТІ, 2000. - 448 с.

3. Довжик О.О. Управлінський облік на сільськогосподарських підприємствах: особливості побудови / О.О. Довжик, С.А. Гаркуша // Вісник Харківського національного аграрного університету ім. В.В. Докучаєва. Серія : Економічні науки. - 2014. - № 3. - С. 124-135.

4. Крушельницька Т.А. Управлінський облік та його складові / Т.А. Крушельницька, Г.С. Павлова // Агросвіт. - 2009. № 20. - C. 21-22.

5. Кушнір T.Б. Управлінський облік у системі організаційного, інформаційного і методичного забезпечення конкурентоспроможності підприємств агропромислового комплексу / Т.Б. Кушнір, В.І. Вербииька // Економічна стратегія і перспективи розвитку сфери торгівлі та послуг : зб. наук. пр. - 2016. - № 2 (24). C. $198-208$.

6. Лишиленко О.В. Бухгалтерський управлінський облік : навч. посібник / О.В. Лишиленко. - Київ : Центр навчальної літератури, 2006. - 254 с. 
7. Лукін В.О. Організація впровадження управлінського обліку / В.О. Лукін // Фінансово-кредитна діяльність: проблеми теорії та практики. - 2012. - Т. 2, № 13.

8. Мельничук Б.В. Управлінський облік - інструмент ефективного менеджменту / Б.В. Мельничук // Агроінком. - 2005. - № 11-12. - С. 51-54.

9. Москаленко В.А. Впровадження управлінського обліку в підприємствах агропромислового комплексу / B.A. Москаленко // Ефективна економіка. - 2013. - № 5. URL: http://nbuv.gov.ua/UJRN/efek_2013_5_35.

10. Олійник O.O. Сегментація управлінського обліку в діяльності інтегрованих аграрних підприємств / О.О. Олійник // Агросвіт. - 2013. - № 10. - С. 32-35.

11. Плотніченко І.Б. Впровадження і розвиток управлінського обліку на підприємстві / І.Б. Плотніченко. URL: www.rusnauka.com/15_APSN_2010/Economics/67832.doc.html.

12. Турова Л.Л. Проблеми впровадження управлінського обліку в Україні / Л.Л. Турова, О.В. Костюнік // Інвестиції: практика та досвід. - 2018. - № 5. - С. 37-40.

13. Яворов В.В. Удосконалення управлінського обліку в сільськогосподарських підприємствах / В.В. Яворов // Економіка АПК. - 2010. - № 3. - С. 107-112.

\section{References:}

1. Byva, V.V. and Matjushina, Ju.I. (2015),»Systema upravlins'kogo obliku: sutnist' zavdannja ta etapy vprovadzhennja», Ekonomika ta derzhava, No. 1, pp. 60-62.

2. Butynec', F.F., Chyzhevs'ka, L.V. and Gerasymchuk, N.V. (2000), Buhgalters'kyj upravlins'kyj oblik, ZhITI, Zhytomyr, $448 \mathrm{p}$.

3. Dovzhyk, O.O. and Garkusha, S.A. (2014), «Upravlins'kyj oblik na sil's'kogospodars'kyh pidpryjemstvah: osoblyvosti pobudovy», Visnyk Harkivs'kogo nacional'nogo agrarnogo universytetu im. V.V. Dokuchajeva, Serija Ekonomichni nauky, No. 3, pp. 124-135.

4. Krushel'nyc'ka, T.A. and Pavlova, G.Je. (2009), «Upravlins'kyj oblik ta jogo skladovi», Agrosvit, No. 20, pp. 21-22.

5. Kushnir, T.B. and Verbyc'ka, V.I. (2016), «Upravlins'kyj oblik u systemi organizacijnogo, informacijnogo i metodychnogo zabezpechennja konkurentospromozhnosti pidpryjemstv agropromyslovogo kompleksu», Ekonomichna strategija i perspektyvy rozvytku sfery torgivli ta poslug, zb. nauk. pr., No. 2 (24), pp. 198-208.

6. Lyshylenko, O.V. (2006), Buhgalters'kyj upravlins'kyj oblik, Centr navchal'noi' literatury, Kyi'v, 254 p.

7. Lukin, V.O. (2012), «Organizacija vprovadzhennja upravlins'kogo obliku», Finansovo-kredytna dijal'nist': problemy teorii' ta praktyky, Vol. 2, No. 13.

8. Mel'nychuk, B.V. (2005), «Upravlins'kyj oblik - instrument efektyvnogo menedzhmentu», Agroinkom, No. 11-12, pp. 51-54.

9. Moskalenko, V.A. (2013), «Vprovadzhennja upravlins'kogo obliku v pidpryjemstvah agropromyslovogo kompleksu», Efektyvna ekonomika, No. 5, URL: http://nbuv.gov.ua/UJRN/efek_2013_5_35

10. Olijnyk, O.O. (2013), «Segmentacija upravlins'kogo obliku v dijal'nosti integrovanyh agrarnyh pidpryjemstv», Agrosvit, No. 10, pp. 32-35.

11. Plotnichenko, I.B. (2010), Vprovadzhennja i rozvytok upravlins'kogo obliku na pidpryjemstvi, URL: www.rusnauka.com/15_APSN_2010/Economics/67832.doc.html

12. Turova, L.L. and Kostjunik, O.V. (2018), «Problemy vprovadzhennja upravlins'kogo obliku v Ukrai'ni», Investycii': praktyka ta dosvid, No. 5, pp. 37-40.

13. Javorov, V.V. (2010), «Udoskonalennja upravlins'kogo obliku v sil's'kogospodars'kyh pidpryjemstvah», Ekonomika APK, No. 3, pp. 107-112.

Панченко Ольга Дмитрівна - аспірантка ННЦ «Інститут аграрної економіки».

Наукові інтереси:

- управлінський облік у сільському господарстві;

- аналітична функція управлінського обліку. 